\title{
O LATROCÍNIO E A SÚMULA 610 DA SUPREMA CORTE: DA ALIENAÇÃO TÉCNICA DO POLÍTICO A ALIENAÇÃO TELEOLÓGICA DO INTÉRPRETE
} THE "LATROCINY" AND THE SUMMARY 610 OF THE SUPREME COURT: FROM THE TECHNICAL ALIENATION OF THE POLITICIAN TO THE TELEOLOGICAL ALIENATION OF THE INTERPRETER

\section{Fábio Aragone Andrade de Oliveira ${ }^{1}$ \\ (Faculdade Damas / PE) \\ George Browne Rêgo ${ }^{2}$ \\ (Faculdade Damas / PE)}

\section{Resumo}

O presente artigo aborda a controvérsia subjacente à estrutura legal do crime de roubo agravado pelo evento morte, a partir de uma perspectiva epistemológica da dogmática penal. O problema central repousa sobre o questionamento acerca da possibilidade de extrair, com base na respectiva descrição legal, um tipo penal cuja estrutura compreenda o homicídio doloso preordenado ao roubo ou, por outro lado, se a esfera de imputação normativa é restrita aos casos em que não há uma conexão de caráter subjetivo entre o roubo e o homicídio, tratando-se tão somente de um crime complexo agravado por um resultado preterintencional. À vista disto, objetiva-se identificar, com base no método hipotético-dedutivo de abordagem, o parâmetro distintivo entre a tentativa e a consumação, a fim de contribuir para uma firme delimitação das diretrizes técnicas do processo de imputação de modo uniforme e dogmaticamente coerente, evitando-se as disparidades que existem no

\footnotetext{
${ }^{1}$ Mestrando em Direito pela Faculdade Damas da Instrução Cristã.

${ }^{2}$ Coordenador do Programa de Pós-graduação em Direito da Faculdade Damas da Instrução Crsitã. Doutor pela Tulane University (USA). Pós-doutor pela Oxford University (UK)
} 
tratamento de determinadas figuras criminosas que se revestem de análoga estrutura típica. Neste passo, delibera-se sobre a relação existente entre a desproporcionalidade punitiva e a alienação técnica do político, acerca do surgimento da equivocada ideia de ambivalência típico-subjetiva e as consequentes vicissitudes da sistematicidade normativa sob a ótica interdisciplinar, bem como sobre a incongruência entre os precedentes jurisprudenciais que consolidaram a Súmula 610 da Suprema Corte e o modo como vem sendo interpretada no direito contemporâneo.

\section{Palavras-chave}

Roubo. Latrocínio. Estrutura legal do crime. Ambivalência típico-subjetiva.

\section{Abstract}

This article broaches the controversy subjacent to the legal structure of the robbery crime aggravated by the death event, from an epistemological perspective in the light of the penal dogmatic. The central problem lies in the investigation about the possibility of extract, based in the respective lawful description, a legal type whose structure comprehends the preordained murder to the robbery or, on the other hand, if the legal imputation sphere is restrict to cases in which does not exist a subjective connection between the robbery and the murder, being only a complex crime aggravated by a preterintencional result. Taking that into account, it is aims to identify, based on hypothetical-deductive approach method, the distinctive parameter between the tentative and the consummation, in order to contribute to systematically and coherently delimitation of the technical imputation guidelines, avoiding treatment disparities on certain crimes that have analogous typical structure. Subsequently, it is broaches the relationship between the punitive disproportion and the technical alienation of the politician, the origin of the misconception about the subjective ambivalence of the legal type and the consequents fickleness of the lawful systematic in the light of the interdisciplinary perspective, as well as the incongruence between the jurisprudential precedents of which originated the Summary 610 of the Supreme Court and the way it has been interpreted in the current juridical scenario.

\section{Keywords}


Robbery. Latrociny. Legal structure of the crime. Subjective ambivalence of the legal type

\section{Introdução}

Em linhas gerais, o problema central da presente pesquisa repousa no seguinte questionamento: seria possível extrair, com base na definição legal do art. $157, \S 3^{\circ}$, um tipo penal em cuja estrutura compreenda a ação de matar para subtrair? Em outras palavras, teria sido a intenção do legislador tipificar um crime doloso agravado por um evento preterintencional ou pretendera abranger os casos em que tal resultado houvesse sido deliberadamente provocado?

Com base nisto, restará indagar: se o agente conscientemente tentar matar alguém, a fim de subtrairos seus pertences, terá praticado uma conduta tipicamente adequada à estrutura legal do art. 157, § $3^{\circ}$ ? Nesta situação, deve-se tomar a perpetração do roubo ou a produção do evento morte como parâmetro distintivo entre a tentativa e a consumação?

Objetiva-se, com isto, contribuir para uma firme delimitação das diretrizes técnicas do processo de imputação de modo uniforme e dogmaticamente coerente, evitando-se as disparidades que existem no tratamento de determinadas espécies que integram o mesmo gênero de infrações, na medida em que se revestem de análoga estrutura típica.

A questão de fundo revela um dilema lógico entre a legalidade e a proporcionalidade penal. De um lado, partindo-se da concepção de que o homicídio doloso representa um corpo alheio à estrutura legal do art. 157, $\S 3^{\circ}$, o excessivo rigor da pena que comporta violaria o "princípio da proporcionalidade, segundo o qual para resultados danosos idênticos deve-se seguir a mesma consequência penal" 
(TAVARES, 2003, p. 242). Em vista disto, surgira no cenário jurídico brasileiro a ilação de ter sido a finalidade do legislador sancionar com maior gravidade o referido delito para abranger também os casos em que o agente houvesse atuado dolosamente. Disto decorre a ideia de ambivalência típico-subjetiva, passando-se a "admitir a possibilidade, indistintamente, de o resultado agravador poder decorrer tanto de culpa quanto de dolo, direto ou eventual" (BITENCOURT, 2012, p. 825). Remanescem, entretanto, as críticas fundadas no argumento de que tal ilação representaria não somente "uma ofensa grave ao princípio constitucional da legalidade", mas também "uma inversão ideológica dos bens jurídicos em jogo" (FRANCO, 2007, p. 360).

Antes mesmo de surgirem as problemáticas contemporâneas acerca do roubo qualificado pelo evento morte, Esther de Figueiredo Ferraz (1948, p. 24) já observara as "divergências de opinião" em "proporções assustadoras quando se trata de interpretar o art. 157, $\S 3^{\circ}$, do Código Penal”. As controvérsias relacionadas ao citado tipo penal que já não eram poucas - viriam a se intensificar com o advento da Lei n. 8.072/1990 - por força da qual fora majorado o respectivo preceito sancionatório - e da Súmula 610 do Supremo Tribunal Federal, a partir da qual florescera no direito brasileiro o entendimento no sentido de que a sua consumação prescindiria da execução do núcleo típico que integra a estrutura do crime base, interpretação contra a qual se dirige a crítica fundada no argumento de que incorreria em nítida convergência com a disciplina legal, por força da qual se exige, para a consumação da infração, a reunião de "todos os elementos de sua definição legal” (art. 14, I).

Seria este, contudo, o autêntico sentido do enunciado sumular? Melhor dizendo, teria sido a intenção da Suprema Corte 
atribuir tratamento excepcional ao mencionado delito em relação ao preceito normativo estabelecido no art. 14, I? Para responder esta e outras questões diretamente relacionadas ao objeto de pesquisa, é necessário valer-se da interpretação teleológica à luz dos precedentes jurisprudenciais que consolidaram a orientação sumulada, a fim de extrair o seu verdadeiro significado. Antes, todavia, é oportuno compreender a correlação entre a desproporcionalidade punitiva e a alienação técnica do político, assim como a origem da multirreferida ideia de ambivalência típico-subjetiva e as consequentes vicissitudes da sistematicidade normativa sob a ótica interdisciplinar, assuntos sobre os quais versam os tópicos inaugurais do presente trabalho.

\section{A desproporcionalidade punitiva e a alienação técnica do político}

No início da década de 1970, o crescimento dos índices de criminalidade estadunidenses reascendera ideologias outrora abandonadas, retomando-se discursos de prevenção do delito através da ampliação da repressão penal. Gabriel Ignacio Anitua (2005, p. 487), em seu excelente trabalho sobre o tema, observa que esta política criminal reflorescera a partir da ideia que os índices delitivos haviam crescido em virtude da diminuição das possibilidades de detenção, condenação e severos castigos. Neste passo, "as considerações dissuasivas deviam ajustar o nível geral de imposição de penas”, bem como os "delinquentes perigosos ou reincidentes deviam ser sujeitos a penalidade mais severas", uma vez que seria muito "mais fácil dissuadir do que reabilitar". 
A este pensamento agregaram-se ideias sociológicas, como a de "deter os suspeitos de sempre antes que realizem fatos graves, devidamente difundidas por todos os meios de acesso massivo", através dos quais angariaram particular "popularidade no âmbito latinoamericano". O "discurso do medo" tornava-se cada vez mais frequente nas medidas repressivas à criminalidade, com o objetivo de transmitir à sociedade uma utópica sensação de segurança. A partir da política criminal de "tolerância zero", declarava-se guerra a crimes como o tráfico ilícito de entorpecentes, as associações criminosas e outros tipos penais - mormente aqueles que tivessem por objeto de tutela o patrimônio -, valendo-se de rigorosíssimas punições impostas pelo legislativo (IGNACIO ANITUA, 2005, p. 488-491).

Enquanto que, de um lado, um "discurso jurídico-penal é uma elaboração intelectual que é oferecida ao poder judicial como projeto de jurisprudência coerente e não contraditória, adequada às leis vigentes" (ZAFFARONI, 2005, p. 74), de outro, os discursos políticos de "lei e ordem" afastam-se dos fundamentos epistemológicos da dogmática penal em prol do "populismo punitivo", buscando-se "satisfazer uma suposta demanda social de maior rigor para aqueles que a "merecem". A "invocação de justiça" tornar-se-ia cada vez mais presente nos discursos de uma política criminal cujo modelo viria a ser importado por países sul-americanos, incluindo o Brasil. Neste passo, penas cada vez mais rigorosas viriam a ser estabelecidas em intervalos de tempo cada vez menores, desprezando-se a proporcionalidade punitiva em prol da ideia de "justo merecimento" (IGNACIO ANITUA, 2005, p. 505-506).

$\mathrm{Na}$ legislação brasileira, por exemplo, pode-se apontar a “atabalhoada Lei 8.072/1990" como nítido paradigma desta ideologia 
punitivista, na medida em que a excessiva majoração punitiva de determinadas infrações que taxara de "hediondas" apresenta-se à margem da epistemologia jurídica, sendo tão somente resultado da política dirigida à redução dos índices de criminalidade, como pode se observar na própria exposição de motivos do projeto legislativo que a originou, cujos argumentos basearam-se na intenção de coibir "atividades delituosas mais nefastas e que cresce dia a dia em qualidade e quantidade", justificando-se que "o aumento da pena destina-se, como é óbvio, a desestimular os eventuais criminosos" (BRASIL, 1990).

A referida lei, segundo Franco (2007, p. 332-334), "atendendo ao contagiante clima psicológico de pavor criado pelos meios de comunicação social e aos interesses imediatos de estratos sociais privilegiados", teria extrapolado os limites da proporcionalidade, na medida em que "alterou, sem obedecer a regras mínimas de coerência e bom senso, sanções punitivas referentes a determinadas figuras criminosas", especialmente "no tratamento sancionatório dado ao tipo da extorsão mediante sequestro", cujo flagrante exagero punitivo "põe a nu o processo seletivo adotado pelo legislador de 90 no sentido de dar tutela mais completa ao patrimônio particular, em detrimento de interesses coletivos mais relevantes como os da administração pública ou de bens jurídicos mais transcendentes como a vida".

Não sem razão, o citado autor ressalta ser juridicamente inaceitável que determinados delitos patrimoniais sejam punidos com maior severidade do que crimes cujo objeto direto de tutela penal reveste-se de maior importância, notadamente a vida humana. Tomando como exemplo o art. $159, \S 3^{\circ}$, pontua que ambas as margens punitivas apresentam-se manifestamente desproporcionais, na medida em que a pena mínima - vinte e quatro anos de reclusão - corresponde 
ao dobro daquela cominada para o homicídio qualificado, ao passo que a pena máxima - trinta anos de reclusão - equivale ao triplo daquela estabelecida para o delito base. Em suas palavras, "o desprezo, no momento legislativo, ao princípio da proporcionalidade poderá, portanto, acarretar, mesmo num regime democrático, a elaboração de leis penais autoritárias", de modo que "a cominação punitiva de determinadas condutas extrapole, de forma desmesurada, a gravidade ou a danosidade que elas representam para a sociedade como um todo" (FRANCO, 2007, p. 333-334).

Análoga desproporcionalidade punitiva é observada no art. 157, $\S 3^{\circ}$, cuja sanção máxima corresponde ao triplo daquela cominada para o respectivo crime base, o que se demonstra injustificável. A desproporção do preceito sancionatório torna-se ainda mais visível ao se admitir a possibilidade de imputação do "latrocínio" na forma consumada sem que ocorresse a subtração patrimonial, situação na qual a pena mínima cominada ultrapassaria o cúmulo das sanções máximas aplicáveis ao delito base e ao homicídio preterintencional (art. 129, § $3^{\circ}$ ).

Por certo, é inegável que o excessivo rigor punitivo de determinadas espécies de infrações agravadas pelo resultado contrastam com o próprio caráter preterintencional do evento morte, o que contribuiu significativamente para a consolidação, no cenário jurídico brasileiro, da ideia de ambivalência típico-subjetiva. Entretanto, como bem observara Franco (2007, p. 332), “a agravação punitiva não obedeceu a nenhum critério de lógica e de técnica legislativa, não se podendo, portanto, dela retirar nenhuma racional conclusão". Pelo contrário, "atribuir à atabalhoada Lei 8.072/90 tal 
requinte de tecnicidade é, sem dúvida, fechar os olhos aos desconcertos e desarmonias que deu origem".

Se, de um lado, não se pode negar que a interpretação teleológica constitui um legítimo método hermenêutico a fim de extrair o autêntico sentido da norma penal, de outro, como bem pontuara Bettiol (1966, p. 134, 135), "não é possível chegar-se à interpretação com fundamento nos preconceitos, ou com base em mera intuição das 'funções' da norma, sem ter tomado contato com a própria norma, com a escama verbal da lei". Em suas palavras, "a referência às fontes substanciais como meio de interpretação pode e deve ocorrer somente dentro dos limites das normas positivas, sem extravasá-los, porque o juiz é chamado a atuar, não a criar ou corrigir o direito que deve aplicar".

Considerando que "o ponto de partida do momento interpretativo, e o seu constante ponto de referência, é o texto legal", não pode o "juiz, na função de intérprete, desprezar o sentido próprio da norma existente e fazer verdadeira inovação de Direito" (BRUNO, 1967, p. 214-215). Com efeito, em matéria penal, a interpretação teleológica submete-se aos estritos limites da legalidade, motivo pelo qual não se poderia partir da ilação de que o legislador teria estabelecido o preceito sancionatório "para indicar, com isso, que o resultado só teria cabimento se fosse doloso" (FRANCO, 2007, p. 361).

Ademais, o infundado argumento de que a disparidade punitiva possibilitaria abranger a esfera de imputação do tipo qualificado pelo evento morte para alcançar os casos em que o agente houvesse atuado com animus necandi demonstra-se, até mesmo, ineficaz para escapar à própria desproporcionalidade das penas, na medida em que isto implicaria em equiparar a punição do homicídio 
preterintencional (art. 129, $\S 3^{\circ}$ ) - que comporta pena máxima equivalente a doze anos de reclusão - ao homicídio qualificado pela conexão teleológica (art. 121, § $2^{\circ}, \mathrm{V}$ ) - cuja sanção pode alcançar trinta anos de reclusão. A própria margem correspondente a dez anos que existe entre as penas - mínima e máxima - estabelecidas no art. $157, \S 3^{\circ}$, demonstra-se insuficiente para evitar esta incoerência.

Sobre o assunto, afirma Juarez Tavares (2003, p. 239-242) que se conceberia os mencionados crimes "como se constituíssem uma categoria própria de tipificação em que, por circunstâncias puramente de política criminal, fossem ignoradas as regras atinentes aos delitos de origem". De acordo com o referido autor, as disparidades punitivas violariam o "princípio da proporcionalidade, segundo o qual para resultados danosos idênticos deve-se seguir a mesma consequência penal". Justamente sobre a desproporcionalidade punitiva das citadas infrações é que repousa a remanescente crítica no sentido de que permanecem baseadas em um núcleo de versari in re illicita, incompatível com os princípios básicos do direito penal (HORMAZÁBAL MALAREE, 1989, p. 1024). Há, todavia, quem concorde com equiparação da pena cominada para o tipo qualificado pelo evento morte à soma das sanções aplicáveis aos crimes membros praticados dolosamente. Neste sentido posicionara-se Nélson Hungria (1955, p. 56) em relação ao "latrocínio", afirmando que "o versari in re illicita, notadamente quando a res illicita é a prática do roubo, justifica essa equiparação".

A questão de fundo revela uma divergência de caráter subjetivo, relacionada a critérios ideológicos que norteariam a quantificação da pena. Sob uma ótica garantista, critica-se a grave ofensa ao princípio da proporcionalidade, sobre o qual não poderia 
prevalecer a mera vontade do legislador de reprimir com extrema severidade determinados delitos apenas por julgá-los tão graves quanto outras infrações que se revestiriam de maior reprovabilidade penal, porquanto estas últimas compreenderiam a vida humana como objeto direto de tutela, cuja lesão decorreria da deliberação criminosa do agente. Em contrapartida, sob uma perspectiva punitivista, pretendese justificar o rigor sancionatório de determinados crimes a partir da política legislativa dirigida à redução dos índices de criminalidade, a fim de reafirmar o poder estatal e, com isto, restaurar a ordem jurídica mediante a veemência na repressão penal de seus autores.

De um modo ou de outro, a alienação técnica do político representa o ponto de união entre estas duas ideologias diametralmente opostas, na medida em que, sob quaisquer das mencionadas concepções, não se poderia afirmar ter o legislador laborado de forma dogmaticamente coerente. Com efeito, não pode o intérprete ignorar a descrição legal do delito, deturpando a sua estrutura típica em virtude das irracionalidades em que incorre o político ao buscar, sob a invocação de discursos de "lei e ordem", transmitir à sociedade uma ilusória - e distorcida - sensação de "justiça", mediante a exasperação da sanção penal sem obedecer a quaisquer critérios epistemologicamente racionais.

\section{A ambivalência típico-subjetiva e as vicissitudes da sistematicidade normativa sob a perspectiva interdisciplinar}

Muito embora o objeto do presente trabalho envolva diretamente o estudo da estrutura jurídica do crime, não se pode 
ignorar o fato de que as normas penais e processuais penais devem ser interpretadas de forma sistemática. Seria um contrassenso valer-se do direito processual penal tão somente como instrumento de aplicação das normas penais, sem levar em consideração as incoerências interdisciplinares porventura existentes. Isolar o objeto direto de disciplinas estritamente correlacionadas, como o direito penal e processual penal, nada mais retrataria senão um indesejável "imperialismo epistemológico" 3 do qual resultariam as mais nefastas incongruências. Com efeito, é necessário ater-se ao fato de que a equivocada ideia de ambivalência típico-subjetiva não apenas incorre na infundada incorporação contra legem da conduta tipificada no art. $121, \S 2^{\circ}, \mathrm{V}$, à estrutura legal do tipo qualificado pelo resultado morte, como consequentemente implica em uma injustificável desarmonia das normas penais e processuais penais vigentes na legislação brasileira.

A título exemplificativo, competiria ao Tribunal do Júri o julgamento do caso no qual o réu, a fim de herdar o patrimônio de seus pais, cometesse um homicídio contra estes. De outra parte, competiria ao magistrado singular o julgamento do caso no qual este mesmo réu, a fim de subtrair os bens de seus pais, praticasse idêntica conduta. Ora, não teriam sido ambos os delitos perpetrados com animus necandi? Não teria o réu, em ambas as hipóteses, demonstrado autêntico desígnio de auferir vantagem patrimonial? Tais fatos criminosos não se revestiriam de análoga reprovabilidade jurídico-penal? Qual seria,

3 Expressão utilizada por Freitas (2012, p. 464), ao tratar da interdisciplinaridade das ciências penais dogmáticas e não dogmáticas, com especial ênfase à história do direito penal. 
então, o fator distintivo da competência material entre os casos em questão?

De acordo com Esther de Figueiredo Ferraz (1948, p. 123127), a expressão "crimes dolosos contra a vida" teria "um sentido técnico jurídico a que não podia alhear-se o legislador constituinte", de modo a abranger todas as "infrações em que o bem jurídico 'vida' é ofendido pelo único ou por um dentre os vários eventos resultantes da conduta do agente", pouco importando a localização traçada "pelos autores do Código Penal". À vista disto, defendera competir ao Tribunal do Júri o julgamento dos delitos qualificados pelo resultado morte, desde que o "elemento subjetivo que acompanhe esses eventos seja o 'dolo', em qualquer de suas diferentes e numerosas modalidades".

Ferraz (1948, p. 130) parte do fundamento de que, sendo o Tribunal Popular competente para julgar os crimes praticados em conexão ao homicídio doloso, não haveria sentido em suprimir de sua competência as infrações em cuja estrutura integrasse o mencionado delito. Em suas palavras, os citados tipos penais comportariam "como elemento essencial ou circunstância agravante, um 'crime doloso contra a vida', arrastando para a competência obrigatória do Júri toda figura complexa em que se encontrar incorporada".

Em análogo entendimento, Gomes Neto (1985, p. 188) enxergara no estupro seguido de morte um "crime doloso contra a vida”, razão pela qual o seu julgamento competiria ao Tribunal Popular, uma vez que, "se pode ser verdade que o agente não quis propriamente o resultado morte, não há dúvida que assumiu o risco de produzi-lo, dando-se assim, pelo menos, o dolo indireto". Assim também se posicionara Heleno Fragoso (1995, p. 213) em relação ao 
"latrocínio", compreendendo que "a competência do juiz singular restringe-se aos casos de resultado morte preterintencional".

O referido entendimento, contudo, não adquiriu muitos adeptos no direito brasileiro, notadamente por ser conflitante com o art. 74, $\S 1^{\circ}$, do Código de Processo Penal, por força do qual competência do Tribunal do Júri restringe-se ao julgamento das infrações tipificadas no primeiro capítulo do Título I da parte especial do diploma vigente. Esta aparente incoerência normativa, entretanto, pode ser superada a partir de uma interpretação sistemática sob a perspectiva interdisciplinar do direito penal e processual penal, considerando-se a trajetória histórica do procedimento legislativo ao longo do qual foram elaborados os dispositivos legais que atualmente regulam a matéria.

Como bem pontuara Giuseppe Bettiol, (1966, p. 134-138) "subsiste no seio das normas uma ordem sistemática frequentemente decisiva para a interpretação teleológica", não se podendo partir da ideia de que seriam "mônadas", tratando-as de forma isolada, "como meras individualidades entre as quais não subsiste nenhuma relação de parentesco". Assim como o elemento racional sistemático contribui significativamente para uma "interpretação intimamente coerente da própria norma”, o elemento histórico, isto é, a "indagação sobre transformações formais da norma em períodos sucessivos, pode também trazer esclarecimentos" acerca de seu conteúdo substancial.

Parafraseando Aníbal Bruno (1967, p. 45), a história penal reveste-se não somente de autonomia científica, mas também de instrumentalidade dogmática, servindo como método de interpretação normativa a partir de dados informativos com base nos quais se investiga a realidade jurídica subjacente à formulação da norma. Em 
suas palavras, "aos elementos gramatical, lógico e sistemático, de que se vale o intérprete, há de juntar-se o elemento histórico, que lhe permite reconstituir o pensamento contido nos textos e determinar as condições que lhe deram origem". Isto significa não apenas considerar a legislação vigente à época da elaboração normativa, mas também analisar "leis estrangeiras que possam ter influído no preceito a interpretar", assim como documentos relacionados à sua idealização, os quais possibilitariam esclarecer "o pensamento que se quis imprimir no texto legal" (BRUNO, 1967, p. 213-217). No mesmo sentido, Freitas ressalta que "a história desempenha um papel relevante no processo hermenêutico", servindo de instrumento para a "elucidação do sentido e alcance da norma" com base nas "circunstâncias históricas que influenciaram o processo de formulação da lei" ${ }^{4}$ tal como projetos e anteprojetos, emendas e exposições de motivos etc.

Relativamente à norma processual penal ora examinada, interessante observar ter sido inserida por força da Lei n. 203/1948, elaborada a partir do projeto legislativo apresentado pelo Senador Olavo Oliveira em 1946. Inicialmente, pretendia-se atribuir ao Tribunal do Júri a competência para o "julgamento de todos os crimes dolosos, de cuja prática resulte morte, seja qual for a sua capitulação, assim como dos que com eles forem conexos". A Comissão de Constituição e Justiça, todavia, através do parecer apresentado pelo

\footnotetext{
4 A história do direito penal, na visão de Freitas (2012, p. 475), deve ser entendida sob duas perspectivas: como disciplina teórica autônoma que compõe o ramo dos saberes não dogmáticos do vasto leque das ciências criminais, e como técnica hermenêutica ou método interpretativo que, em suas palavras, se encontra "a serviço da dogmática do direito penal", destinando-se a permitir que "o intérprete descubra o significado e alcance da norma para aplicar o direito às situações conflituosas concretas".
} 
Senador Ferreira de Souza, manifestara-se no sentido de ser impossível "encartar as espécies delituosas descritas nos artigos do Código Penal a que se refere a ementa entre os 'crimes contra a vida' a que se refere $o$ art. 141, § 28 da Constituição" à época vigente, visto que, nestes casos, "a lesão à vida não decorre do ato como manifestação de uma resolução criminosa, não foi desejada, não é sequer fruto de uma deliberação instantânea" (FERRAZ, 1948, p. 120-122).

O mencionado projeto, então, foi modificado para excluir da redação legal os delitos que não estivessem previstos no Título I, Capítulo I, da parte especial do diploma vigente. Com a nova redação, foi aprovado e transformado na Lei n. 263/1948, a partir da qual o art. $74, \S 1^{\circ}$, do Código de Processo Penal passou a vigorar nos seguintes termos: "compete ao Tribunal do Júri o julgamento dos crimes previstos nos arts. $121,1^{\circ}, 121 \S 2^{\circ}, 122$, parágrafo único, $123,124,125$, 126 e 127 do Código Penal, consumados ou tentados". Através desta mesma Lei, também foi modificado o art. 78, I, do mesmo diploma processual. $\mathrm{O}$ citado dispositivo - que antes estabelecera a prevalência da competência do magistrado singular sobre o Tribunal Popular no caso de conexão ou continência - passou a vigorar com a seguinte redação: "no concurso entre a competência do júri e a de outro órgão da jurisdição comum, prevalecerá a competência do júri” (FERRAZ, 1948, p. 122).

No caso em questão, observa-se ter sido afastada a competência do Tribunal Popular para o julgamento das infrações qualificadas pelo evento morte justamente em virtude do fato de que, nestes casos, "a lesão à vida não decorre do ato como manifestação de uma resolução criminosa, não foi desejada, não é sequer fruto de uma deliberação instantânea" (FERRAZ, 1948, p. 121-122), razão pela qual 
a teleologia política referente à elaboração da referida norma contrasta com a própria ilação de ter sido a finalidade do legislador sancionar com maior gravidade o delito para abranger também as situações nas quais o resultado agravante houvesse sido intencionalmente provocado pelo autor.

Sob uma ótica rigorosamente técnica, inexiste na legislação brasileira uma figura típica que se possa atribuir a denominação de "latrocínio", a menos que se entenda como tal uma espécie de homicídio qualificado pela finalidade delituosa (art. 121, § $2^{\circ}, \mathrm{V}$ ), que não somente se reveste de caráter especial sob o prisma de sua estrutura subjetiva, mas também envolve matéria alheia à competência do magistrado singular. Com efeito, a ilação de que o excessivo rigor do preceito sancionatório do art. $157, \S 3^{\circ}$, permitira extrair, de sua estrutura legal, um tipo penal ao qual se subsumiria a ação intencional de matar alguém com o desígnio específico de subtrair, nada mais revelaria senão uma desastrosa contradição epistemológica em cuja essência carrega não apenas "uma ofensa grave ao princípio constitucional da legalidade", mas também "uma inversão ideológica dos bens jurídicos em jogo" (FRANCO, 2007, p. 360).

Havendo pluralidade de atos cometidos com desígnios autônomos - um dirigido à consumação do delito base e outro à consecução do evento qualificador -, "não ocorre um crime qualificado pelo resultado, mas dois crimes" (REALE JÚNIOR, 2004, p. 266-267), mormente se um dos desígnios consiste no animus necandi teleologicamente vinculado à perpetração de outra infração, situação na qual prevaleceria a imputação do homicídio qualificado pela finalidade delituosa (art. 121, § $2^{\circ}, \mathrm{V}$ ), Do contrário, não somente se presumiria contra legem uma unidade jurídica de múltiplos delitos 
praticados em concurso, como se incorreria em nítida desigualdade no tratamento de determinadas espécies que integram o mesmo gênero de crimes.

Esta ideia de ambivalência típico-subjetiva não apenas se demonstra dogmaticamente incoerente, mas sobretudo reflete negativamente no tratamento da tentativa. As famigeradas hipóteses desenvolvidas acerca da tentativa e consumação do "latrocínio", conquanto bastante difundidas no cenário doutrinário e jurisprudencial brasileiro, consistem em uma construção tautológica e grosseira, alheia ao rigor técnico exigido na interpretação e aplicação da lei penal. Dentre os vários julgados incoerentes acerca do tema, talvez o mais desacertado haja sido o posicionamento firmado pela quinta Turma do Superior Tribunal de Justiça no julgamento do habeas corpus $n$. 80.491/RJ, ocasião na qual se entendeu ser prescindível o emprego de violência para a configuração da tentativa no roubo qualificado pelo evento morte, vale dizer, não ser relevante a "ocorrência de lesão corporal, seja de natureza leve ou grave, sendo suficiente a comprovação de que o agente tinha a intenção de matar para subtrair coisa móvel de outrem e de que o delito não se consumou" (BRASIL, 2008).

Ignorou-se, portanto, que a própria descrição legal do art. 157, $\S 3^{\circ}$, - "se da violência resulta morte" - pressupõe a produção do resultado morte a partir da ofensa física praticada, sem a qual não ocorre a subsunção fática - direta ou indireta - aos elementos constitutivos do tipo penal. No diploma penal vigente, inexiste uma infração patrimonial cujo núcleo típico compreenda a conduta de matar alguém "para executar, depois, a subtração" (FRANCO, 2007, p. 359). Se o agente pratica a ação intencional de matar com o desígnio 
específico de assegurar a execução, ocultação, impunidade ou vantagem de outro crime, resta configurado o concurso delitivo entre o homicídio doloso - notadamente qualificado pela finalidade (art. $\left.121, \S 2^{\circ}, \mathrm{V}\right)$ - e o delito a que estiver conexo, consumados ou tentados, conforme o caso. ${ }^{5}$

Em julgados mais recentes, inclusive, o Supremo Tribunal Federal "decidiu pela necessidade de exame sobre a existência de dolo homicida do agente, para, nos casos em que se lhe apure animus necandi, dar por caracterizado concurso material entre homicídio tentado e roubo consumado", concluindo ser "impossível a punição por tentativa de latrocínio, quando o homicídio não se realize" (BRASIL, 2008). Esta decisão, sem dúvidas, representa significativo avanço jurisprudencial em direção a uma interpretação rigorosamente técnica da estrutura legal do mencionado tipo penal. No entanto, ainda não se pode afirmar ter se alcançado, de modo dogmaticamente coerente, uma firme delimitação do respectivo processo de imputação.

\section{A literalidade da Súmula 610 da Suprema Corte e a alienação teleológica do intérprete}

5 Neste sentido, cf. Franco (2007, p. 359-360) e Jório (2008, p. 254). Na doutrina argentina, assim também se posicionaram Damianovich de Cerredo (2000, p. 122), Levene (1977, p. 278) e Soler (1992, p. 286). Sob uma ótica mais ampla, relativamente aos crimes agravados pelo evento morte de modo geral, cf. Alves (2007, p. 266-267), Reale Júnior (2004, p. 266-267) e, na doutrina estrangeira, Beling (2002, p. 169), Diez Ripollés (1982, p. 632), Mezger (1957, p. 131-132) e Welzel (1997, p. 87). 
Se, de um lado, remanescem controvérsias acerca da imputação das infrações qualificadas pelo resultado a título de tentativa, de outro, a redação legal do Código Brasileiro é bastante clara e objetiva quanto à consumação do fato criminoso: consumado é o delito no qual "se reúnem todos os elementos de sua definição legal" (art. 14, I). Com efeito, não há que se discutir a literalidade normativa: ou as circunstâncias fáticas equivalem integralmente aos elementos constitutivos do tipo penal e têm-se um crime consumado ou as circunstâncias fáticas são insuficientes para tanto.

Especificamente tratando-se do roubo qualificado pelo evento morte, no entanto, são enfrentadas maiores dificuldades, notadamente em face da Súmula 610 da Suprema Corte, a partir da qual florescera no direito brasileiro a teste de que, para a consumação da citada infração, seria prescindível a execução do núcleo típico que integra a estrutura do delito base. Esta interpretação, todavia, incorre em nítida convergência com a disciplina legal, na medida em que, à míngua do êxito na subtração patrimonial, não ocorre subsunção fática direta aos elementos constitutivos do tipo penal, cuja estrutura objetiva apresenta-se incompleta.

Tal entendimento faria sentido se o resultado qualificador recaísse sobre um crime de atentado - v.g., a evasão mediante violência contra a pessoa (art. 352) - ou se houvesse uma norma através da qual, de forma expressa e inequívoca, se estabelecesse esta possibilidade, a exemplo daquelas previstas nos revogados diplomas de 1830 (art. 274) e 1890 (art. 360). Assim pretendera o legislador brasileiro de 1969, ao estabelecer ser "irrelevante se a lesão patrimonial deixa de consumarse" (art. 167, $\S 5^{\circ}$ ). O referido diploma, entretanto, nunca chegou a entrar em vigor. 
Seria este, porém, o autêntico sentido do enunciado sumular? Melhor dizendo, teria sido o verdadeiro objetivo da mencionada súmula consolidar um tratamento excepcional ao roubo qualificado pelo evento morte em relação ao preceito normativo estabelecido no art. 14, I? De sua simples leitura, não há dúvidas de que é possível extrair esta interpretação.

Não se pode ignorar, contudo, que uma orientação sumulada é fruto de reiteradas decisões judiciais semelhantes, com o escopo de uniformizar a jurisprudência, evitando, assim, a insegurança jurídica resultante da diversidade de entendimentos conflitantes no âmbito de competência da respectiva Corte. Há casos em que os citados enunciados não demonstram margens para dúvidas acerca de seus respectivos significados.

Eventualmente, no entanto, pode a redação sumular apresentar ambiguidade ou obscuridade. Nestas situações, cabe ao técnico basear-se nos precedentes que a consolidaram, valendo-se da interpretação teleológica a fim de extrair o seu legítimo significado. A alienação teleológica do intérprete pode conduzir a entendimentos completamente arbitrários, alheios à própria essência do enunciado, desvirtuando-se do verdadeiro objetivo pelo qual foi construído. À vista disto, convém pedir vênia aos nobres juristas que atualmente representam a doutrina majoritária, para extrair da multirreferida súmula o seu autêntico sentido à luz dos precedentes jurisprudenciais que a consolidaram.

Dentre estes precedentes, pode-se citar o habeas corpus n. 56.171/RJ, impetrado contra a decisão do Tribunal de Justiça do Rio de Janeiro que manteve a sentença de primeira instância na qual o réu fora condenado por "latrocínio" na forma tentada, justamente por não 
ter logrado êxito na subtração patrimonial, conquanto da violência empregada em sua tentativa houvesse decorrido a morte da vítima. No caso em questão, o impetrante sustentara "a incompetência do juiz singular para o julgamento", argumentando que, "cuidando-se de subtração patrimonial tentada e homicídio consumado, o fato constitui homicídio qualificado consumado e não tentativa de latrocínio". O Relator Ministro Cordeiro Guerra, em seu voto, ressaltara que o entendimento até então predominante seria no sentido de que, nestas situações, "quer se considere que o latrocínio já se consumou, quer se entenda que ele foi simplesmente tentado - esta questão não está em causa no presente recurso - a competência pra o processo e julgamento é do juiz singular". Em suas palavras, não seria "necessário, ainda, uma definição doutrinária sobre casos como o dos autos, se o latrocínio se consuma, ou é simplesmente, tentado", reservando-se "para, em outra oportunidade, optar entre as soluções propostas - latrocínio consumado ou tentado em casos como os dos autos" (BRASIL, 1978). Em idêntico sentido, posicionou-se o Ministro Cunha Peixoto no julgamento do habeas corpus n. 56.704/SP, ocasião na qual ressaltara predominar o entendimento de que, ocorrendo a morte da vítima, restaria "caracterizado, de qualquer modo, o latrocínio, seja tentado, quer consumado, questão esta que não foi ventilada, nem é objeto de exame neste habeas corpus" (BRASIL, 1979a).

Como se observa, a questão em causa nos mencionados julgados cingia-se à esfera de imputação da citada infração, concluindo-se que abrangeria também os casos nos quais a produção do resultado qualificador decorresse da tentativa de execução do delito base, motivo pelo qual competiria ao magistrado singular o julgamento do fato. Neste ponto, o entendimento sumulado apresenta perfeita 
conformidade com a interpretação técnica da lei penal: há, de fato, crime de "latrocínio"; não se afirma, todavia, haver "latrocínio" consumado.

Além dos precedentes jurisprudenciais anteriormente referidos, existem outros julgados que também mantiveram a condenação por "latrocínio" tentado em casos nos quais ocorrera a morte da vítima a partir da violência exercida com a finalidade de efetuar a subtração patrimonial não consumada. Neste sentido, convém mencionar o habeas corpus $n$. 57.420/RJ, julgado naquele mesmo ano, ocasião na qual o Ministro Relator Djaci Falcão, com perspicácia, esclarecera o posicionamento à época firmado pela Suprema Corte, ao concluir que, "apesar de a denúncia capitular o crime como tentado, por não se ter concretizado a subtração, descreve a consumação do homicídio, praticado durante a execução de um roubo com emprego de arma", hipótese na qual "configura-se o latrocínio, segundo a nossa jurisprudência". Perceba-se que esta afirmativa não merece reparo, na medida em que se alega restar configurada - e não consumada - a mencionada infração em virtude da unidade jurídica de sua estrutura complexa (BRASIL, 1979b).

Poucos, por outro lado, são os precedentes relacionados a casos em que o réu houvera sido condenado por "latrocínio" consumado sem que houvesse ocorrido a subtração patrimonial. Nestes julgados, entretanto, o impetrante arguira a incompetência do juízo ou buscara a desclassificação do tipo penal. A título exemplificativo, convém mencionar o habeas corpus $n$. 56.817/SP, cujo paciente já houvera anteriormente requerido "por três vezes sucessivas, a revisão do julgado", tendo sido o primeiro pedido "indeferido e, dos subsequentes, não se tomou conhecimento, por se tratar de mera 
reiteração". Na ocasião, o então Subprocurador-Geral da República, Francisco de Assis Toledo, em seu parecer, sustentou a inviabilidade do "reexame de prova, na via sumaríssima do habeas corpus, para transformar-se uma condenação por latrocínio consumado em tentativa de roubo". Ao final, complementara os seus argumentos contrários à concessão da ordem com a lição de Francesco Carrara, no sentido de que "no latrocínio, o delito é perfeito, embora o culpado, depois de matar a vítima, não tenha podido consumar o furto" (BRASIL, 1979c).

Interessante esclarecer, porém, que nem sempre a doutrina estrangeira se refere ao "latrocínio" como sinônimo de roubo qualificado pelo evento morte. Como bem observa Alberto Silva Franco (2007, p. 360), "no homicídio preordenado ao roubo, a ciência penal histórica e o atual direito penal comparado veem um homicídio qualificado (latrocinium) ou uma modalidade de assassinato", não um crime patrimonial. Na legislação argentina, por exemplo, apesar de existir o roubo agravado pelo resultado morte (art. 165), a doutrina se refere ao "latrocínio" como espécie de homicídio criminis causa (art. 80, VII). Diferentemente do que ocorre no Direito Brasileiro, contudo, interpreta-se as respectivas infrações de forma sistemática e dogmaticamente coerente: o "latrocínio" - assim compreendido o homicídio praticado com a finalidade de perpetrar o roubo - prevalece sobre o delito patrimonial agravado pelo resultado, cuja esfera de imputação restringe-se aos casos em que não há uma conexão de caráter subjetivo, vale dizer, uma relação de meio e fim. ${ }^{6}$

\footnotetext{
6 Neste sentido, cf. Damianovich de Cerredo (2000, p. 122), Levene (1977, p. 278) e Soler (1992, p. 286).
} 
Sob a ótica do direito comparado, portanto, a expressão "latrocínio" não se reveste de uma única definição, podendo ser empregada não apenas como referência ao roubo agravado pelo evento morte - que constitui um crime patrimonial, cuja execução pressupõe a ofensa intencional à integridade física, a partir da qual decorre um resultado objetivamente previsível -, mas também como espécie de homicídio agravado pela conexão ou finalidade delituosa - que constitui uma infração contra a vida, em cuja estrutura típica compreende a ação intencional de matar com o desígnio específico de subtrair. Neste último caso, trata-se de um tipo penal análogo àquele previsto no art. $121, \S 2^{\circ}, \mathrm{V}$, do Código Penal Brasileiro, cuja consumação ocorre com a efetiva lesão jurídica à vida humana, pouco importando "que o fato punível cuja execução se tenha em vista não se pratique, nem mesmo seja praticável, ou que o agente não venha a alcançar qualquer dos outros fins procurados” (BRUNO, 1972, p. 79).

Justamente sob esta perspectiva, Francesco Carrara (1956, p. 136) afirmara que "o homicídio visando o furto, que se chama latrocínio", pertence à classe do "delito que serviu de meio", por ser "mais grave que aquele que o agente se propunha como fim". Em suas palavras, "o meio é o que define o delito qualificado pelo fim; não é o meio que qualifica o fim". Com efeito, o entendimento do Catedrático da Universidade de Pisa - no sentido de que o latrocínio "é perfeito, embora o culpado, depois de matar a vítima, não tenha podido consumar o furto" (CARRARA, 1956, p. 274) - é plenamente aplicável ao homicídio qualificado pela conexão teleológica (art. 121, § $2^{\circ}, \mathrm{V}$ ), mas não ao roubo qualificado pelo evento morte (art. 157, $\S 3^{\circ}$ ), sobretudo porque inexistiria um crime análogo a esta última infração no Diploma Italiano. 
Por certo, a doutrina e a jurisprudência são livres para defender que a consumação do delito tipificado no art. 157, $\S 3^{\circ}$, ocorreria com a produção do resultado qualificador, independentemente da subtração patrimonial. O equívoco, no entanto, reside na pretensão de justificar este posicionamento a partir de uma visão distorcida das lições de Carrara - ou de qualquer doutrina estrangeira que se refira ao "latrocínio" como espécie de homicídio agravado pela conexão ou finalidade delituosa - ou, simplesmente, apontar a Súmula 610 como fundamento legítimo para tanto, tal como o fizera a quinta Turma do Superior Tribunal de Justiça no julgamento do recurso especial n. 523.396/RS, ao reformar a decisão proferida pelo Tribunal de Justiça do Rio Grande do Sul que, em sede de apelação, houvera reconhecido "o delito em sua forma tentada" em face da inexecução da subtração patrimonial. Na ocasião, acolheu-se pretensão recursal do Ministério Público para restabelecer a sentença condenatória "pela prática do crime de latrocínio consumado" (BRASIL, 2003). O mesmo ocorrera no julgamento de outros recursos de competência daquela Corte, originando-se uma interpretação extensiva - e, de certo modo, distorcida - da redação sumular, a partir da qual se firmou um entendimento que ultrapassa os seus próprios fundamentos, na medida em que não encontra respaldo na maior parte dos precedentes jurisprudenciais que a consolidaram.

Partindo-se da concepção do diploma penal como a "Carta Magna do delinquente" (ZAFFARONI, 2005, p. 110), em desfavor do réu não poderia ser aplicada uma pena à margem da lei. Considerando que, sob o prisma do sistema legal brasileiro atualmente vigente, a consumação da infração depende da reunião de "todos os elementos de sua definição legal” (art. 14, I), não se poderia aplicar a pena cominada 
ao delito consumado sem que isto ocorresse, a menos que houvesse uma norma através da qual, de forma expressa e inequívoca, se estabelecesse esta possibilidade, tal como outrora pretendera o legislador na frustrada reforma penal de 1969. Se assim o fizesse, todavia, incorreria o político no absurdo de possibilitar a fixação de uma pena correspondente a trinta anos de reclusão quando a soma das sanções máximas aplicáveis aos respectivos crimes membros sequer alcançariam dois terços daquela cominada ao tipo qualificado pelo resultado.

Justamente por não ter sido adotado este critério na reforma legislativa de 1984, torna-se impossível tomar a produção do evento morte como parâmetro de distinção entre a tentativa e a consumação, visto que a sua materialização seria indispensável à imputação - seja na forma tentada, seja na forma consumada - da respectiva infração. Se, de um lado, a consumação do delito equivale à correspondência integral das circunstâncias fáticas aos elementos constitutivos do tipo penal, de outro, é o elemento subjetivo que atribui sentido à conduta típica, cuja finalidade revela se houve, ou não, tentativa no crime de estrutura complexa (REALE JÚNIOR, 2004, p. 293).

Com efeito, se o resultado morte transcende a esfera do dolo - elemento este indispensável para a imputação da infração à míngua da produção do evento material do qual depende a subsunção direta do fato -, não se poderia falar em crime agravado por um resultado tentado, mas tão somente em crime tentado agravado por um evento preterintencional efetivamente produzido, isto é, quando "o resultado mais grave se produz pela ação de tentativa", v.g., a "morte da mulher se produz pela tentativa de estupro” (WELZEL, 1956, p. 200). 
Nas palavras de Frederico Marques (1965, p. 364-373), apenas "pode-se afirmar admissível um crime tentado que sofra agravação por evento qualificador do delito base". Deste modo, a morte decorrente da violência empregada na tentativa de subtração de bem móvel alheio caracterizaria o roubo tentado qualificado pelo resultado morte. Assim também se posicionara Bento de Faria (1956, p. 50), de acordo com o qual a consumação do "latrocínio" restaria prejudicada à míngua da subtração patrimonial, "podendo, entretanto, se verificar a tentativa, embora ocorra o homicídio". Na doutrina contemporânea, Paulo José da Costa Júnior (1996, p. 481) e Rogério Greco (2011, p. 444) filiam-se ao posicionamento sustentado pelos citados juristas, compreendendo verificar-se a tentativa no caso em que ocorre a morte da vítima a partir da violência exercida com a finalidade de perpetrar o roubo não consumado. Há, nestes casos, a execução de uma conduta idônea à materialização dos elementos constitutivos do crime base, cujo objeto direto de tutela penal é, não efetivamente lesado, mas exposto a risco de lesão.

Por certo, os tipos qualificados pelo evento morte representam uma violação à vida humana, independentemente do bem jurídico tutelado em face da posição topográfica que ocupam no diploma legal (FERRAZ, 1948, p. 44). Não pode o intérprete, porém, ignorar o conteúdo instrumental que este bem jurídico possui no processo hermenêutico, ou seja, a "função de precisa distinção e consequente classificação dos ilícitos penais" a partir da "sistematização dos crimes em diversos agrupamentos", reunidos "conforme os elementos que os constituem, os essentialia delicti" (LUNA, 1985, p. 123). 
Como bem pontuara Bettiol (1966, p. 134-138), "a verdadeira exegese ocorre somente após a individualização do escopo, depois da verificação do bem jurídico ou do valor tutelado pela norma”. Em suas palavras, "a ordem formal que o legislador observa nas suas disposições reflete frequentemente a ordem substancial que subsiste nos valores tutelados, o que, para fins exegéticos, é verdadeiramente decisivo". Não se pode, portanto, disciplinar um caso concreto a partir de uma concepção teleológica dissociada das "diretivas superiores que regem grupos de normas ou que formam a ossatura substancial do sistema".

Com efeito, se o legislador houvesse pretendido tipificar as infrações qualificadas pelo resultado morte como crimes dolosos contra a vida, não apenas teria constado expressamente a ação de matar em suas respectivas descrições legais, mas também as teria inserido no Título I, Capítulo I, da parte especial do diploma vigente. Se houve por bem prever o evento morte como uma circunstância agravante de caráter objetivo, não se poderia atribuí-la ao agente senão quando "o fato em que ela se consubstancia tenha sido inteiramente realizado", apesar de incidir "sobre um fato principal incompleto" (BETTIOL, 1971, p. 225).

\section{Conclusões}

Hodiernamente, é indiscutível que a mera causalidade imprevisível não constitui fundamento idôneo à responsabilidade penal, sob a égide da garantia da culpabilidade. Ainda que o resultado criminoso decorra de uma conduta ilícita, não pode ser imputado ao agente senão quando este for capaz de prevê-lo e evitá-lo. É justamente 
sobre a previsibilidade e evitabilidade que se funda a reprovabilidade penal.

Se, de um lado, a previsibilidade objetiva do evento criminoso é concebida como limite positivo à sua imputação, de outro, a possibilidade de adequação típica a um crime doloso cujos elementos objetivos correspondam àqueles definidos como circunstância agravante deve ser interpretada como limite negativo à subsunção do fato ao tipo agravado pelo resultado, na medida em que o primeiro reveste-se de caráter especial sob a ótica de sua estrutura subjetiva, prevalecendo sobre esta última infração.

Partindo-se da concepção de que os delitos qualificados pelo evento morte compreendem em sua estrutura o homicídio preterintencional, torna-se impossível tomar a produção do resultado qualificador como parâmetro de distinção entre a tentativa e a consumação. Não sendo o evento qualificador - que decorre da violência elementar à conduta típica - imputável a título de dolo, a sua produção torna-se imprescindível à subsunção do fato ao preceito incriminado na norma penal e, por conseguinte, à própria imputação - seja na forma tentada, seja na forma consumada - do respectivo crime.

A configuração da consumação ou tentativa, portanto, depende da perpetração - ou não - do delito base: consumada é a infração cujos elementos constitutivos equivalem integralmente às circunstâncias do fato concreto; tentado é o crime cujo núcleo típico não é realizado, conquanto da tentativa de realizá-lo decorra a produção do resultado considerado mais grave do que a violência física elementar à respectiva conduta. Existe, nestes casos, a interrupção involuntária de atos idôneos à consumação do delito base cuja 
execução pressupõe a ofensa à integridade física a partir da qual decorre um evento objetivamente previsível: a maior gravidade da lesão ou a morte da vítima.

Esta solução, embora aparente ser inconcebível, apresenta perfeita conformidade com a interpretação técnica da lei penal. Isto porque, tratando-se de uma norma extensiva da tipicidade, a configuração da tentativa depende da incorporação do verbo "tentar" ao núcleo do tipo penal, vale dizer, a adequação típica ocorre com a produção do resultado qualificador a partir da tentativa de realização da conduta típica que integra a estrutura do crime base.

Este evento corresponde a um desdobramento causal objetivamente previsível - no decorrer da execução criminosa interrompida por circunstâncias alheais à vontade do agente, o qual não logrou êxito em sua finalidade de alcançar a consumação do delito base. É justamente a materialização do multirreferido desdobramento causal que, dentro dos limites da previsibilidade culpável, possibilita a subsunção - direta ou indireta - do fato ao preceito incriminado nas infrações qualificadas pelo resultado.

Idêntico raciocínio é perfeitamente aplicável ao tão controverso roubo qualificado pelo evento morte (art. 157, $\S 3^{\circ}$ ). Não há sentido em atribuir tratamento desigual a determinadas espécies que integram o mesmo gênero de crimes. A estrutura típica do resultado morte que qualifica o delito base apresenta, em todos os casos, os mesmos elementos constitutivos. A desigualdade no tratamento dos vários tipos agravados pelo resultado não somente se reveste de incoerência dogmática, mas sobretudo acarreta insegurança jurídica, na medida em que inexiste uma firme delimitação das diretrizes técnicas do processo de imputação. 
A orientação consolidada na Súmula 610 da Suprema Corte não afirma ser prescindível a subtração patrimonial para a consumação do "latrocínio", mas apenas para a configuração da citada infração. Neste ponto, o entendimento firmado apresenta perfeita conformidade com a interpretação técnica da lei penal: há, de fato, crime de "latrocínio"; o enunciado sumular - assim como muitos precedentes jurisprudenciais que o consolidaram - não ingressa no mérito da tentativa ou consumação. Com efeito, a imputação dos delitos qualificados pelo resultado - seja na forma consumada, seja na forma tentada - demanda a efetiva produção do evento qualificador.

Se, de um lado, a consumação da infração depende da reunião de todos os elementos de sua definição legal (art. 14, I), de outro, a imputação do crime na forma tentada pressupõe a falta de êxito na materialização do núcleo típico que integra a estrutura do delito base. É justamente sobre este - e não sobre o resultado qualificador - que reside o fator distintivo entre a tentativa e a consumação. Há, nesta situação, não um crime qualificado pelo evento tentado, mas um crime tentado qualificado pelo evento efetivamente produzido: o homicídio preterintencional, isto é, a morte decorrente da violência física elementar ao delito base que não se consumou por circunstâncias independentes da vontade do agente.

Por certo, compete ao magistrado, no exercício de sua função técnica, a interpretação e aplicação da lei penal a partir de sua livre convicção baseada no acervo fático-probatório do caso concreto. Ao optar pelo desmembramento das infrações e aplicação cumulativa das respectivas penas, poderá fazê-lo, uma vez que decidiria em favor do réu, impondo-lhe uma sanção mais branda do que aquela aplicável ao tipo qualificado pelo resultado. 
Não poderia, todavia, condenar-lhe por um crime qualificado pelo resultado senão quando produzido o resultado que o qualifica, tampouco por um crime consumado senão quando reunidos todos os elementos de sua definição legal. No primeiro caso, o fato concreto transcende a esfera de imputação do tipo penal, porquanto a tentativa de produzir a morte configuraria o homicídio doloso na forma tentada; no segundo, é a esfera de imputação do tipo penal que transcende o fato concreto, visto que implicaria em nítida violação ao art. 14, I.

Para que o mencionado delito pudesse ser imputado sem que ocorresse a subtração patrimonial, seria necessário que o legislador estabelecesse, de forma expressa e inequívoca, esta possibilidade. Se assim o fizesse, contudo, caberia ao político majorar a pena cominada aos crimes membros, de modo a evitar o absurdo de possibilitar a fixação de uma pena equivalente a trinta anos de reclusão quando a soma das sanções máximas aplicáveis destas infrações sequer alcançariam dois terços daquela cominada ao tipo qualificado pelo resultado.

$\mathrm{O}$ argumento de que esta disparidade punitiva possibilitaria abranger a esfera de imputação da norma para alcançar também os casos em que o agente houvesse atuado com animus necandi não somente se demonstra ilegítimo, como ineficaz para escapar à própria desproporcionalidade das penas, na medida em que isto implicaria em equiparar a punição do homicídio preterintencional (art. 129, $\S 3^{\circ}$ ) ao homicídio qualificado (art. 121, $\S 2^{\circ}, \mathrm{V}$ ). A própria a margem correspondente a dez anos que existe entre as penas - mínima e máxima - previstas no art. $157, \S 3^{\circ}$, demonstra-se insuficiente para evitar tal incoerência. 
Perceba-se que a punição daquele que houvesse atuado com propósito homicida seria mais branda do que se deveria, posto que o cúmulo das penas aplicáveis para o delito patrimonial e o homicídio qualificado ultrapassaria aquela cominada para o crime agravado pelo resultado. Qual seria, então, o propósito desta ambivalência típicosubjetiva? Punir com menos rigor do que se deveria a conduta criminosa que se reveste de maior reprovabilidade ao mesmo tempo em que se pune com extrema severidade a ação delituosa que se reveste de menor reprovabilidade? Por certo, a direção traçada inverte a lógica dos valores.

Em última análise, observa-se que não existem fundamentos idôneos sob esta famigerada concepção de "latrocínio", que nada mais retrata senão a injustificável incorporação contra legem da conduta tipificada no art. 121, $\S 2^{\circ}, \mathrm{V}$, à estrutura legal do art. 157, $\S 3^{\circ}$, em uma pura manifestação de desprezo ao conteúdo da própria norma, com o inequívoco objetivo ideológico de realizar uma verdadeira inovação de direito.

O próprio método teleológico de interpretação das normais penais e processuais penais consideradas sistematicamente mormente se associado ao elemento histórico, referente ao conteúdo do processo legislativo ao longo do qual fora elaborada a regra prevista no art. 74 do diploma processual vigente - contrasta com a ilação de ter sido a finalidade do legislador, ao sancionar com maior rigor determinadas infrações agravadas pelo evento morte, abranger a esfera de imputação normativa aos casos em que este resultado houvesse sido intencionalmente provocado pelo agente. Isto porque, ao contrário do que se pretendera inicialmente, o julgamento dos delitos agravados pelo evento morte fora afastado da competência do Tribunal do Júri 
justamente em virtude do fato de que, nestes casos, a lesão à vida humana não decorreria da deliberação criminosa do autor e, portanto, não se poderia enquadrá-los como crimes dolosos contra a vida.

Fugiria ao objeto do presente artigo discutir os aspectos positivos e negativos de se outorgar a juízes leigos a competência para o julgamento de matérias que exigiriam conhecimento técnico. De um ou de outro modo, é necessário que se atribua correlativo tratamento jurídico - material e processual - a infrações que se revestem de análoga estrutura típica. O roubo seguido de morte, seja qual for o nomen iuris e o preceito sancionatório a este atribuído, constitui um delito essencialmente patrimonial, cuja execução pressupõe a ofensa intencional à integridade física, a partir da qual decorre um resultado preterintencional.

Com efeito, não pode o intérprete ignorar a descrição legal do crime, deturpando a sua estrutura típica em razão da alienação técnica do político que, sob a invocação de discursos de "lei e ordem", buscara transmitir à sociedade uma ilusória - e distorcida - sensação de "justiça”, mediante a exasperação da sanção penal sem obedecer a quaisquer critérios epistemologicamente racionais.

Ante o dilema lógico entre a proporcionalidade penal e a legalidade, esta última há de prevalecer, notadamente porque o político, no exercício de sua função legiferante, não está isento de desacertos, mas ao técnico cabe apenas interpretar a lei vigente, sendolhe vedado valer-se do processo hermenêutico para inovar o direito positivo, uma vez que sequer haveria algum método interpretativo idôneo a deturpar o conteúdo normativo.

Enquanto que, de um lado, a alienação técnica do político torna-se cada vez mais presente em um país no qual a legislação é 
construída à margem da coerência dogmática e a proporcionalidade das penas já não mais passa de uma velha utopia, de outro, cabe à ciência jurídica romper os paradigmas construídos sobre os devaneios políticos, a fim de desmistificar os paradoxos tão desconcertantes quanto às próprias irracionalidades em que incorre o legislador.

\section{Referências}

ALVES, Roque de Brito. Direito Penal: parte geral. Recife: edição do autor, 2007.

BELING, Ernst von. Esquema de Derecho Penal: la doctrina del delitotipo. Buenos Aires: Livreria El Foro, 2002.

BETTIOL, Giuseppe. Direito Penal. São Paulo: Revista dos Tribunais, 1966. v. 1.

BETTIOL, Giuseppe. Direito Penal. São Paulo: Revista dos Tribunais, 1971. v. 2.

BITENCOURT, Cezar Roberto. Comentários ao Código Penal. São Paulo: Saraiva, 2012.

BRASIL. Exposição de motivos do Projeto de Lei n. 50/1990. Diário do Congresso Nacional, Brasília, 18 maio 1990. Seção 2, p. 2212. 
BRASIL. Superior Tribunal de Justiça. 5a Turma. Habeas corpus n. 80.491/RJ. Relator Ministro Arnaldo Esteves Lima. Brasília, 23 set. 2008. Diário de Justiça de 03 nov. 2008.

BRASIL. Superior Tribunal de Justiça. 5a Turma. Recurso Especial n. 523.396/RS. Relator Ministro Félix Fischer. Brasília, 12 ago. 2003. Diário de Justiça de 22 set. 2003.

BRASIL. Supremo Tribunal Federal. 2a Turma. Habeas corpus n. 56.171/RJ. Relator Ministro Cordeiro Guerra. Brasília, 15 ago. 1978. Diário de Justiça de 22 set. 1978.

BRASIL. Supremo Tribunal Federal. 1a Turma. Habeas corpus n. 56.704/SP. Relator Ministro Cunha Peixoto. Brasília, 20 fev. 1979. Diário de Justiça de 23 mar. 1979a.

BRASIL. Supremo Tribunal Federal. 2a Turma. Habeas corpus n. 56.817/SP. Relator Ministro Moreira Alves. Brasília, 23 de fevereiro de 1979. Diário de Justiça de 30 mar. 1979b

BRASIL. Supremo Tribunal Federal. 2a Turma. Habeas corpus n. 57.420/RJ. Relator Ministro Djaci Falcão. Brasília, 13 nov. 1979. Diário de Justiça de 14 dez. 1979c.

BRASIL. Supremo Tribunal Federal. 2a Turma. Habeas corpus n. 91.585/RJ. Relator Ministro Cezar Peluso. Brasília, 16 set. 2008. Diário de Justiça de 19 dez. 2008. 
BRUNO, Aníbal. Direito Penal: parte especial. Rio de Janeiro: Forense, 1972. t. 4.

BRUNO, Aníbal. Direito Penal: parte geral. Rio de Janeiro: Forense, 1967. t. 1.

CARRARA, Francesco. Programa do Curso de Direito Criminal: parte geral. São Paulo: Saraiva, 1956. v. 1.

COSTA JÚNIOR, Paulo José da. Comentários ao Código Penal. São Paulo: Saraiva, 1996.

DAMIANOVICH DE CERREDO, Laura T. A. Delitos contra la propiedad. Buenos Aires: Editorial Universidad, 2000.

DIEZ RIPOLLÉS, José Luis. Los delitos calificados por el resultado y el artículo $3^{\circ}$ del proyecto de Código penal español de 1980. Anuario de Derecho Penal y Ciencias Penales. Madri: Ministerio de Justicia y Consejo Superior de Investigaciones Científicas, 1982.

EPICURO, 341-270 a.C. Antologia de textos. In: Os pensadores. São Paulo: Abril Cultural, 1985.

FARIA, Bento de. Código Penal Brasileiro. Rio de Janeiro: Record, 1956. v. 5.

FERRAZ, Esther de Figueiredo. Os delitos qualificados pelo resultado no regime do código penal de 1940. 139 p. Dissertação de livre- 
docência, Faculdade de Direito da Universidade de São Paulo. São Paulo, 1948.

FRAGOSO, Heleno Cláudio. Lições de Direito Penal: parte especial. Rio de Janeiro: Forense, 1995.

FRANCO, Alberto Silva. Crimes Hediondos. São Paulo: Revista dos Tribunais, 2007.

FREITAS, Ricardo. Quando os caminhos de Têmis e Clio se encontram: o direito penal e as possibilidades do conhecimento histórico das ideias penais. In: História do Direito e do Pensamento Jurídico em Perspectiva. São Paulo: Atlas, 2012.

GOMES NETO, F. A. Novo Código Penal Brasileiro. São Paulo: Brasiliense, 1985. v. 3.

GRECO, Rogério. Código Penal Comentado. Rio de Janeiro: Impetus, 2011.

HORMAZÁBAL MALAREE, Hernán. Imputación objetiva y subjetiva en los delitos calificados por el resultado. Anuario de Derecho Penal y Ciencias Penales. Madri: Ministerio de Justicia y Consejo Superior de Investigaciones Científicas, 1989.

HUNGRIA, Nélson. Comentários ao Código Penal. Rio de Janeiro: Forense, 1955. v. 7. 
IGNACIO ANITUA, Gabriel. Historias de los pensamientos criminológicos. Buenos Aires: Del Puerto, 2005.

JÓRIO, Israel Domingos. Latrocínio. Belo Horizonte: Del Rey, 2008.

LEVENE, Ricardo. El delito de homicidio. Buenos Aires: Depalma, 1977.

LUNA, Everardo da Cunha. Capítulos de Direito Penal: parte geral. São Paulo: Saraiva, 1985.

MARQUES, José Frederico. Tratado de Direito Penal. São Paulo: Saraiva, 1965. v. 2.

MEZGER, Edmund. Tratado de Derecho Penal. Madri: Editorial Revista de Derecho Privado, 1957. t. 2.

REALE JÚNIOR, Miguel. Instituições de Direito Penal: parte geral. Rio de Janeiro: Forense, 2004.

SOLER, Sebastian. Derecho Penal Argentino. Buenos Aires: Tipografica Editora Argentina, 1992. t. 4.

TAVARES, Juarez. Teoria do Injusto Penal. Belo Horizonte: Del Rey, 2003.

WELZEL, Hans. Derecho Penal Alemán. Santiago: Editorial Jurídica de Chile, 1997. 
WELZEL, Hans. Derecho Penal: parte general. Buenos Aires: Roque Depalma, 1956.

ZAFFARONI, Eugenio Raúl. En torno de la cuestión penal. Buenos Aires: B de F, 2005. 